\title{
PENGARUH PROMOSI MEDIA SOSIAL, CELEBRITY ENDORSER, DAN PERCEIVED QUALITY TERHADAP KEPUTUSAN PEMBELIAN
}

\author{
Stefasnus Kevin Sirait \\ Sisnuhadi \\ Fakultas Bisnis Universitas Kristen Duta Wacana \\ Email korespondensi: ssisnuhadi@staff.ukdw.ac.id
}

\begin{abstract}
ABSTRAK
Penelitian ini dilakukan untuk mengeksplorasi dampak promosi media sosial, celebrity endorser, dan perceived quality terhadap keputusan pembelian pada produk SuperTrack Clothing di Daerah Istimewa Yogyakarta. Regresi linier berganda diterapkan untuk signifikansi antar variabel, dan uji koefisien determinasi. Variabel independen dalam penelitian ini yaitu promosi media sosial, celebrity endorser, dan perceived quality sedangkan variabel dependen dalam penelitian ini adalah keputusan pembelian. Penelitian ini menemukan bahwa bahwa semakin gencar promosi media sosial akan meningkatkan keputusan pembelian, semakin terkenal celebrity endorser akan meningkatkan keputusan pembelian, semakin kuat perceived quality yang dimilliki konsumen, akan mendorong peningkatan keputusan pembelian.
\end{abstract}

Kata Kunci: promosi media sosial, celebrity endorser, perceived quality, dan keputusan pembelian

\begin{abstract}
This research was conducted to explore the impact of social media promotion, celebrity endorsers, and perceived quality on purchasing decisions on SuperTrack Clothing products in the Special Region of Yogyakarta. Multiple linear regression was applied for significance between variables, and the coefficient of determination test. The independent variables in this study are social media promotion, celebrity endorser, and perceived quality, while the dependent variable in this study is the purchase decision. This study found that the more intense social media promotion will increase purchasing decisions, the more well-known celebrity endorsers will improve purchasing decisions, the stronger the perceived quality that consumers have, will encourage an enhance in purchasing decisions.
\end{abstract}

Keywords: social media promotion, celebrity endorser, perceived quality, and purchasing decisions 


\section{PENDAHULUAN}

Yogyakarta dikenal oleh masyarakat luas dengan sebutan "Jogja Istimewa" menawarakan berbagai tempat hiburan wisata untuk semua kalangan umur, bukan hanya tempat wisata di kalangan komunitas motor juga termasuk komunitas motor terbanyak di Indonesia, bermacam - macam komunitas motor dari yang kelas rendah sampai tinggi ada di Yogyakarta. Dengan banyaknya komunitas motor, banyak pelaku usaha clothing baju yang membuat baju yang berhubungan dengan tema komunitas motor.

Supertrack Clothing adalah sebuah brand apparel perusahaan industri rumah tangga (home industry) yang menghasilkan pakaian jadi. Nama Supertrack clothing diambil dari nama pemilik dan nama komunitas Rx King yang ada di Yogyakarta. Nama pemilik Supri yang diubah menjadi "Super" yang artinya istimewa, sedangkan "Track" itu club motornya yang mempunyai kepanjangan “Tawon Racing King”.

Supertrack Clothing selalu berinovasi untuk menciptakan produk-produk baru. Mencipatkan suatu yang berbeda dan unik, baik itu produk dan layanan yang diberikan untuk konsumen. Dewasa ini, banyak perusahaan memanfaatkan internet untuk melakukan operasinya, salah satunya adalah untuk media promosi. Dalam penggunaan internet, dunia bisnis mengalami perubahan sistem dalam cara bertransaksi, perdagangan, pemasaran, dan penyimpanan informasi.

Menurut Kotler \& Amstrong (2015: 10), “adanya teknologi yang canggih dengan jaringan internet memudahkan interaksi secara langsung antara konsumen dan pelaku bisnis”. Segala apapun bisa dilakukan dengan berkembangnya teknologi yang canggih, baik itu sekedar mencari informasi ataupun menjalankan bisnis. Hal ini membuat penjual yang memanfaatkan kecanggihan teknologi untuk melakukan pemasaran atau mempromosikan produk - produk yang mereka jual melalui media sosial baik itu web marketing ataupun media sosial. Media sosial dianggap lebih efektif bagi pelaku bisnis untuk memasarkan atau mempromosikan produk atau jasa, menjalin atau membangun hubungan baik dengan kosumen. Promosi media sosial yang menjadi tujuan penelitian adalah Instagram dan Youtube. Instagram dan Youtube menjadi saluran penjualan, pemasaran influencer, dan promosi produk.

Menurut Shimp (2003 : 455), "celebrity endorser adalah memanfaatkan seorang artis, entertainer, atlet, dan publik figur yang mana banyak diketahui oleh orang banyak untuk keberhasilan dibidangnya masing-masing dari bidang yang didukung”. Para celebrity endorser diharapkan menjadi juru bicara merek agar cepat melekat di benak konsumen, sehingga konsumen mau membeli merek tersebut.

Menurut Aaker (1996), persepsi kualitas merupakan persepsi konsumen terhadap keseluruhan kualitas atau keunggulan suatu produk atau jasa layanan yang sama dnegan maksud yang diharapkannya. Persepsi kualitas adalah salah satu kunci dimensi ekuitas merek. Perceived quality sesungguhnya tidak dapat ditetapkan secara obyektif karena lebih merupakan pada persepsi dan kepentingan pelanggan. Persepsi kualitas yang dirasakan oleh konsumen berpengaruh terhadap kesediaan konsumen tersebut untuk membeli sebuah produk (Chapman dan Wahlers, 1999 dalam Khasanah 2015).

$$
\text { Kotler \& Amstrong }
$$
menjelaskan bahwa keputusan pembelian adalah tahap dalam proses pengambilan keputusan pembeli di mana konsumen benar-benar membeli. Tjiptono (2011) menjelaskan bahwa keputusan pembelian adalah sebuah proses dimana konsumen mengenal masalahnya, mencari informasi mengenai produk atau merek tertentu dan mengevaluasi secara baik masing-masing alternatif tersebut dapat memecahkan masalahnya, yang kemudian mengarah kepada keputusan pembelian.

Dari promosi media sosial, celebrity endorser, dan perceived quality sangatlah 
berpengaruh dengan keputusan pembelian. Karena suatu produk akan dilihat menarik untuk di minati banyak konsumen perlu adanya promosi yang menjadi tren, celebrity endorser sebagai suatu kepercayaan produk berkualitas, sehingga akan timbul keputusan pembelian konsumen.

Berdasarkan uraian latar belakang masalah yang telah dikemukakan di atas, maka penelitian ini bertujuan untuk mengetahui 1) pengaruh promosi media sosial terhadap keputusan pembelian produk kaos Supertrack Clothing di Daerah Istimewa Yogyakarta, 2) pengaruh celebrity endorser terhadap keputusan pembelian produk kaos Supertrack Clothing di Daerah Istimewa Yogyakarta, 3) pengaruh perceived quality terhadap keputusan pembelian produk kaos Supertrack Clothing di Daerah Istimewa Yogyakarta

Penelitian ini diharapkan dapat menambah referensi di bidang perilaku konsumen, khususnya yang menyangkut tentang promosi di media social, celebrity endorser, perceived quality dan keputusan pembelian.Selain itu, hasil peneltian ini dipergunakan sebagai masukan bagi perusahan dalam dalam mdempengaruhi konsumen untuk melakukan keputusan pembelian.

\section{LANDASAN TEORI DAN PENGEMBANGAN HIPOTESIS Promosi Media Sosial}

Salah satu meningkatkan keberhasilan penjualan adalah promosi, promosi digunanakan perusahaan untuk memperkenalkan produk kepada masyarakat luas supaya kesadaran terhadap suatu produk atau jasa perusahaan lebih meningkat dan untuk menginformasikan manfaat dari suatu produk yang digunakan oleh perusahaan. terdapat beberapa pengertian promosi menurut para ahli. Menurut Kotler \& Amstrong (2015:496), definisi promosi adalah sarana dimana perusahaan berusaha untuk menginformasikan, membujuk dan mengingatkan konsumen baik secara langsung atau tidak langsung tentang produk dan merek yang mereka jual. Dengan berkembangnya teknologi media promosi, media sosial menjadi salah satu promosi yang efisien bagi perusahaan, karena perusahaan tidak membutuhkan biaya untuk mempromosikan produk, dan jangkauannya pun lebih luas.

Menurut Kotler \& Amstrong (2015:568), media sosial merupakan sarana bagi konsumen untuk berbagi informasi teks, gambar, audio, dan video dengan satu sama lain dan dengan perusahaan dan sebaliknya. Untuk mempermudah promosi penjualan perusahaan kini lebih memilih cara yang praktis, salah satunya menggunakan media sosial. Menurut Gunelius (2011: 15) tujuan paling umum penggunaan sosial media adalah untuk membangun hubungan, membangun merek, publisitas, promosi, dan riset pasar. Sementara itu, Gunelius (2011) menjelaskan terdapat empat elemen yang dijadikan sebagai variabel kesuksesan pemasaran melalui media sosial, yaitu: Content Creation, Content Sharing, Connecting, dan Community

Celebrity Endorser

Menurut Shimp (2003), endorser adalah sebagai pendukung iklan atau juga yang dikenal sebagai bintang iklan yang mendukung produk yang diiklankan. Berdasarkan pengertian endorser di atas, maka dapat disimpulkan bahwa endorser adalah orang-orang yang menyampaikan pesan. Shimp (2003) menjelaskan bahwa endorser dibagi menjadi tiga yaitu :

1. Orang biasa adalah merupakan orangorang yang tidak berasal dari kalangan selebriti yang disebut sebagai non selebriti yang menggunakan atau mendukung suatu produk.

2. Selebriti adalah tokoh (aktor, penghibur, atau atlit) yang dikenal masyarakat didalam bidang-bidang yang berbeda.

3. Para ahli adalah orang-orang yang pendapatnya mengenai suatu produk 
tertentu dituruti oleh orang-orang yang kurang tahu tentang produk tersebut. Biasanya, mereka mempunyai peran yang penting dalam komunikasi dari mulut ke mulut tentang suatu produk.

\section{Perceived Quality}

Pengertian kesan kualitas (perceived quality) menurut Aaker (1996:24), adalah presepsi pelanggan pada keseluruhan kualitas atau keunggulan suatu produk atau jasa yang sesuai dengan yang diharapkan pelanggan. Tjiptono (2011:97) menjelaskan bahwa persepsi kualitas adalah penilaian konsumen terhadap keunggulan atau superioritas produk secara keseluruhan. Studi empiris dilakukan Menurut Aaker (1996: 124), perceived quality, merupakan informasi berupa persepsi konsumen terhadap kualitas produk. Perceived quality dipengaruhi oleh kualitas produk dan kualitas pelayanan yang diberikan.Kualitas produk dapat dilihat dari kinerja produk, ciri khas produk, dapat dipercaya, daya tahan produk, kemampuan memberikan service, dan apakah produk tampak berkualitas. Menurut Kotler dan Keller (2016: 9) menjelaskan bahwa terdapat 6 dimensi kualitas produk yang perlu diperhatikan, yaitu: mutu kinerja (performance), keandalan (reliability), keistimewaan (feature), daya tahan (durability), mutu kesesuaian (conformance quality), dan gaya (style).

\section{Keputusan Pembelian}

Proses pengambilan keputusan pembelian sangat dipengaruhi oleh perilaku konsumen. Proses tersebut sebenarnya merupakan proses pemecahan masalah dalam rangka memenuhi keinginan atau kebutuhan konsumen. Menurut Engel et al. dalam Sangadji dan Sopiah (2013:332), perilaku pembelian adalah proses keputusan dan tindakan orang-orang yang terlibat dalam pembelian dan pengguanan produk. Adapun pendapat dari Peter dalam Sangadji dan Sopiah (2013:332) menyebutkan bahwa, pengambilan keputusan konsumen adalah proses pemecahan masalah yang diarahkan pada sasaran. Engel at al dalam Sangadji dan Sopiah (2013:334) mengemukakan lima tahapan perilaku konsumen dalam pengambilan keputusan pembelian, yaitu: pengenalan kebutuhan, pencarian informasi, evaluasi alternatif, keputusan pembelian, dan hasil.

\section{Hubungan Promosi Media Sosial dengan Keputusan Pembelian}

Media sosial menjadi salah satu media yang paling banyak digunakan oleh masyarakat, yang menjadi target perusahaan untuk melakukan promosi, karena minim biaya. Promosi media sosial sangat berpengaruh terhadap keputusan pembelian. Pamungkas dan Zuhroh (2016) dan Bate'e (2019), menemukan bahwa promosi media sosial berpengaruh positif signifikan terhadap keputusan pembelian.

H1: Terdapat pengaruh promosi media sosial terhadap keputusan pembelian.

\section{Hubungan Celebrity Endorser dengan Keputusan Pembelian}

Celebrity endorser menjadi model dari iklan produk, yang menjadi daya tarik konsumen untuk tertarik membeli produk yang diiklankan. Celebrity endorser sangat berpengaruh terhadap keputusan pembelian. Oktafiani dan Silaningsih (2015) dan Ayu dan Jatra (2016) melaporkan bahwa Celebrity endorser berpengaruh positif signifikan terhadap keputusan pembelian.

H2: Terdapat pengaruh celeberty endorser terhadap kepuasan pembelian.

\section{Hubungan Perceived Quality dengan Keputusan Pembelian}

Perceived quality sebagai presepsi kualitas yang di nilai oleh konsumen, sebelum menentukan pembeli produk tersebut, dari penilaian presepsi konsumen akan melakukan keputusan pembelian produk tersebut. Perceived quality sangat berpengaruh terhadap keputusan pembelian. Terbukti pada penelitian 
terdahulu Lie et al. (2017), melaporkan bahwa presepsi kualitas (preceived quality) berpengaruh secara postifif dan signifikan terhadap keputusan pembelian. Sedangkan Devi dan Anom. (2019) dan Harjati dan Sabu (2014) menemukan bahwa perceived quality mempengaruhi keputusan pembelian pada sepatu Nike.

H3: Terdapat pengaruh perceived quality terhadap keputusan pembelian.

Berdasarkan landasan teori dan konsep yang dijabarkan di atas maka penelitian ini menganalisis pengaruh promosi melalui media social, celebrity endorser, dan perceived quality terhadap keputusan pembelian. Variabel yang digunakan dalam penelitian ini adalah variabel independen yaitu promosi melalui media sosial (X1), celeberty endorser (X2) dan perceived quality (X3) serta variabel dependen yaitu keputusan pembelian (Y). Penelitian ini digunakan untuk meneliti pengaruh dari masing-masing variabel independen terhadap variabel dependen. Gambar 1 dibawah ini menunjukkan hubungan antara independent variabel dan dependen variabel yang akan di teliti.

\section{METODE PENELITIAN}

Metode penelitian pada dasarnya merupakan cara ilmiah untuk mendapatkan data dengan tujuan dan kegunaan tertentu. Dalam penelitian ini menggunakan metode kuantitatif. Menurut Sugiyono (2014:18), metode kuantitatif yaitu data penelitian berupa angka - angka dan analisis menggunakan statistik. Sedangkan jenis penelitian ini adalah asosiatif, yaitu bertujuan untuk mengetahui apakah ada pengaruh atau hubungan antar variabel bebas dengan variabel terikat. Adapun yang menjadi variabel bebas adalah promosi media sosial, celebrity endorser, dan perceived quality sedangkan variabel terikat adalah keputusan pembelian.

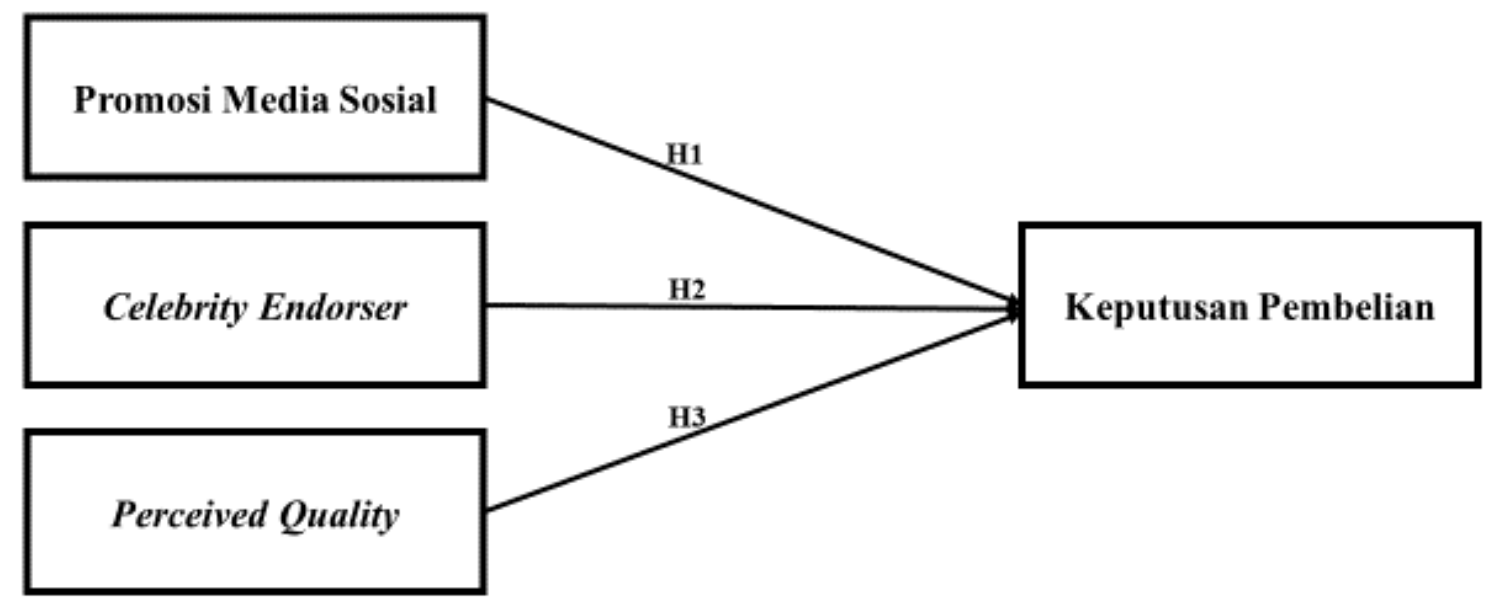

Gambar 1. Model Penelitian

\section{Populasi dan Sampel}

Dalam penelitian ini, yang menjadi populasi dalam penelitian ini adalah seluruh pembeli (konsumen) Supertrack Clothing di Yogyakarta. Sedangkan sampel yang akan diteliti sebanyak 100 responden. Teknik pengambilan sampel dalam penelitian ini mengunakan metode purposive random sampling. Adapun syarat anggota sampel dalam penelitian ini adalah pembeli (konsumen) SuperTrack Clothing di Kota Yogyakarta, Batul, Sleman, Kulon Progo, dan Gunung Kidul.

\section{Variabel dan Definisi Operasional Variabel}

Menurut Sugiyono (2014:96) variabel penelitian adalah "suatu atribut atau sifat 
atau nilai dari orang, obyek, organisasi atau kegiatan yang mempunyai variasi tertentu yang ditetapkan oleh peneliti untuk dipelajari dan kemudian ditarik kesimpulananya”.

a. Variabel terikat (dependen variabel), variabel yang digunakan sebagai variabel ini adalah keputusan pembelian.

b. Variabel bebas (independen variabel), variabel yang digunakan sebagai variabel ini adalah promosi media sosial, celebrity endorser dan kualitas pelayanan.

\section{Definisi Operasional Variabel}

Keputusan Pembelian

Keputusan Pembelian adalah Keputusan pembelian adalah suatu proses dimana konsumen melakukan pembelajaran terlebih dahulu tentang sebuah produk sebelum melakukan pembelian. Adapun indicator keputusan pembelian adalah :

$>$ Pengenalan kebutuhan

Pencarian informasi

Evaluasi Alternatif

Keputusan Pembelian

Perilaku pasca pembelian

\section{Promosi Media Sosial}

Menurut Kotler dan Amstrong (2015;568), media sosial merupakan sarana bagi konsumen untuk berbagi informasi teks, gambar, audio, dan video dengan satu sama lain dan dengan perusahaan dan sebaliknya. Menurut Gunelius (2011) terdapat empat elemen yang dijadikan sebagai variabel kesuksesan social media marketing :

Content Creation

> Content Sharing

$>$ Connecting

$>$ Community Building

\section{Celebrity Endorser}

Menurut Shimp (2003) endorser adalah sebagai pendukung iklan atau juga yang dikenal sebagai bintang iklan yang mendukung produk yang diiklankan. Sedangkan menurut Royan (2005) endorser adalah icon atau sosok tertentu yang sering juga disebut sebagai direct source (sumber langsung) untuk mengantarkan sebuah pesan dan atau memperagakan sebuah produk atau jasa dalam kegiatan promosi yang bertujuan untuk mendukung efektifitas penyampaian pesan produk. Menurut Shimp (2003:218) atribut dari endorser yaitu :

$>$ Credibility

$>$ Attractiveness

$>$ Power

\section{Perceived Quality}

Persepsi konsumen akan kualitas suatu produk atau jasa menentukan nilai dari produk atau jasa tersebut dan berpengaruh secara langsung kepada keputusan pembelian konsumen. Menurut Kotler dan Amstrong (2015: 129), terdapat 6 dimensi kualitas produk yang perlu diperhatikan:

$>$ Mutu kinerja (performance)

$>$ Keandalan (reliability)

$>$ Keistimewaan (feature)

Daya tahan (durability)

Mutu kesesuaian (conformance quality)

Gaya (style)

\section{Metode Pengumpulan Data dan Skala Pengukuran Data}

Metode pengumpulan data yang digunakan adalah dengan Kuesioner. Metode Kuesioner menurut Arikunto (2010:168) adalah sejumlah pertanyaan tertulis yang digunakan untuk memperoleh informasi dari responden dalam arti laporan tentang pribadinya atau hal-hal yang ia ketahui. Kuesioner terdiri dari serentetan pertanyaan/pernyataan dimana responden hanya memberikan tanda cek (V) pada pilihan jawaban yang telah disiapkan. Responden pengisi kuesioner adalah masyarakat. Dalam menanggapi pertanyaan kuesioner, maka digunakan pengukuran dengan skala likert. Skala likert didesain untuk menelaah sebarapa kuat subjek setuju atau tidak setuju dengan pertanyaan pada skala 5 titik dengan susunan sebagai berikut: 
Alternatif Jawaban Sangat Tidak Setuju (STS) diberi skor 1

Alternatif Jawaban Tidak Setuju (TS) diberi skor 2

Alternatif Jawaban Netral (N) diberi skor 3

> Alternatif Jawaban Setuju (S) diberi skor 4

Alternatif Jawaban Sangat Setuju (SS) diberi skor 5

Skala likert digunakan untuk menjawab dan mengukur indicator peneltian.

\section{HASIL DAN PEMBAHASAN Uji Validitas}

Proses perhitungan dilakukan dengan SPSS kemudian nilai $r$ hitung yang diperoleh dibandingkan dengan nilai $r$ tabel sesuai dengan jumlah $\mathrm{n}$ dan taraf signifikan $(\alpha)=5 \%$ dalam pengujian validitas kuesioner dikatakan valid apabila $r$ hitung lebih besar dari $r$ tabel (Sugiyono, 2014:348). Untuk $r$ tabel $n=30$ (n-k dalam penelitian ini yaitu 30-2 = 28) dan tingkat signifikan 5\% adalah sebesar 0,239. Uji validitas dalam penelitian ini menunjukkan bahwa semua nilai $r$ hitung dari kuesioner yang diuji beradad diatas nilai $\mathrm{t}$ table, sehingga kuesioner dianggap valid.

\section{Uji Reliabilitas}

Tinggi rendahnya reliabilitas ditunjukkan oleh suatu angka koefisien reliabilitas. Untuk mengukur tinggi rendahnya reliabilitas salah satunya dengan menggunakan teknik pengukuran koefisien alpha. Semakin mendekati koefisien 1 alpha cronbrach dari variabel semakin tinggi konsistensi jawaban skor dari tiap indikator. Menurut Arikunto (1998:138), penggunaan teknik Alpha-Cronbach akan menunjukkan bahwa suatu instrumen dapat dikatakan handal (reliabel) bila memiliki koefisien reliabilitas atau alpha sebesar 0,6 atau lebih. Tabel 1 dibawah ini menunjukkan hasil uji reliabilitas. Semua variabel yang dipergunakan dalam penelitian ini memiliki nilai Cronbach's Alpha diatas 0,6 sehiangga dianggap reliabel.

Tabel 1. Hasil Uji Reabilitas

\begin{tabular}{cc}
\hline Variabel & Cronbach's Alpha \\
\hline Promosi Media Sosial & 0,876 \\
Celebrity Endoreser & 0,789 \\
Percieved Quality & 0,856 \\
Keputusan Pembelian & 0,709
\end{tabular}

Sumber: Data primer diolah (2020)

\section{Hasil Analisis Deskriptif}

Dalam analisis ini data primer yang berhasil dikumpulkan oleh peneliti yang berasal dari kuesioner dengan menggunakan google from akan dianalisis untuk mengetahui karakteristik responden penelitian. Dalam penelitian ini jumlah sampel yang digunakan sebanyak 100 responden.

Partisipan dalam penelitian ini adalah adalah 100 orang responden. Sebanyak 66 orang berjenis kelamin laki - laki dengan jumlah persentase sebesar 66,7 \% dan responden dengan jenis kelamin perempuan sebanyak 33 orang dengan persentase sebesar 33.3\%.
Sementara itu, sebanyak 69 dari 100 responden penelitian ini berusia antara 21 30 tahun dengan persentase 69,7\%, 18 responden berusia 31 - 40 tahun dengan persentase 18,2\%, 9 responden berusia 10 20 tahun dengan persentase 9,1\%, 3 responden berusia 40-50 tahun dengan persentase $3 \%$, dan 0 responden berusia $>50$ tahun degan persentase $0 \%$. Dapat disimpulkan bahwa responden dalam penelitian ini di dominasi oleh responden dengan usia 21 - 30 tahun dengan persentase $69,7 \%$.

Berdasarkan pada lokasi tempat tinggal, diketahui bahwa 58 dari 100 responden penelitian ini berlokasi di Kota 
Yogyakarta dengan persentase 58,8\%, 24 responden berlokasi di Sleman dengan persentase $24,2 \%$, ada 2 lokasi yang sama sama memiliki 6 responden berlokasi di Bantul dan Gunung Kidul dengan persentase $6,1 \%$, 5 responden belokasi di Kulon Progo dengan persentase 5,1\%. Dapat disimpulkan bahwa responden dalam penelitian ini di dominasi oleh responden berlokasi di Kota Yogyakarta sebesar 58,8 $\%$.

Jika dilihat dari sisi jenis pekerjaan, diketahui bahwa 53 dari 100 responden dalam penelitian ini merupakan mahasiswa/pelajar dengan proesentase 53,4\%, 18 responden dengan pegawai swasta dengan proesentase 18\%, 17 responden sebagai Wirausaha dengan proesentase $17,2 \%$, ada 2 pekerjaan yang sama - sama memiliki 4 responden sebagai ASN dan pekerjaan lainnya dengan proesentase $4 \%$, dan 3 responden sebagai TNI/POLRI dengan persentase 3\%. Oleh karenanya dapat disimpulkan bahwa jenis pekerjaan responden dalam penelitian ini didominasi oleh mahasiswa dengan proesentase sebesar $72 \%$.

Dari sudut pandang tingkat penghasilan, responden dengan penghasilan per bulan sebesar > Rp. 2.000.000 terdapat 23 dengan persentase 30,3\%, responden dengan penghasilan per bulan sebesar Rp.1.000.001 - Rp.1.500.000 sebanyak 23 responden dengan persentase 23,2\%, penghasilan Rp. 1.500.001 - Rp. 2.000.000 sebanyak 21 responden dengan persentase 21.2\%, penghasilan sebesar Rp. 500.001 -
Rp. 1.000 .000 sebanyak 14 responden dengan persentase $14,1 \%$, dan responden dengan penghasilan sebesar $<$ Rp. 500.000 sebanyak 11 responden dengan persentase 11,1\%. Dari data tersebut dapat disimpulkan bahwa penelitian ini didominasi oleh responden dengan penghasilan per bulan sebesar Rp.1.000.001 - Rp.1.500.000 sebanyak 23 responden dengan persentase 23,2\%.

Berdasarkan Pendidikan Terakhir dapat diketahui bahwa 49 dari 100 responden penelitian pendidikan terakhirnya adalah SMA/SMK dengan persentase sebesar 49,5\%, 44 responden dengan pendidikan terakhir D3/S1 dengan persentase $44,4 \%, 3$ responden dengan pendidikan terakhir SMP dengan persentase 3\%, 2 responden dengan pendidikan terakhir SD dengan persentase $2 \%$, dan 1 responden dengan pendidikan terakhir lainnya dengan persentase 1\%. Sehingga dapat disimpulkan bahwa responden dalam penelitian ini didominasi responden dengan pendidikan terakhir SMA/SMK dengan persentase sebesar $49,5 \%$ sejumlah 49 responden.

\section{Analisis Regresi Linier Berganda}

Analisis ini dilakukan untuk mengetahui arah hubungan antara variabel promosi media sosial, celebrity endorser, perceived quality (independen) terhadap variabel keputusan pembelian (dependen). Adapun hasil pengolahan data menggunakan SPSS dapat dilihat pada Tabel 2 di bawah ini:

Tabel 2. Hasil Regresi Linier Berganda

\begin{tabular}{lcc}
\hline \multicolumn{1}{c}{ Model } & $\boldsymbol{\beta}$ & Sig \\
\hline Konstan & 3.038 & .049 \\
Promosi Media Sosial & .218 & .031 \\
Celebrity Endorser & .356 & .001 \\
Perceived Quality & .194 & .020 \\
\hline
\end{tabular}

Dependen variabel: Keputusan Pembelian

Sumber: Data Primer Diolah (2020)

Berdasarkan data diatas nilai koefisien masing - masing variable adalah sebagai berikut :

$\mathrm{Y}=\mathrm{a}+\beta 1 \mathrm{X}_{1}+\beta 2 \mathrm{X}_{2}+\beta 2 \mathrm{X}_{3}$
$Y=3.038+0,218 X_{1}+0,356 X_{2}+0,194$ $\mathrm{X}_{3}$ 
Persamaan di atas mengandung arti bahwa jika usaha promosi media sosial ditingkatkan maka akan semakin mendorong keinginan untuk mengambil keputusan pembelian. Selanjutnya jika perusahaan menggunakan celebrity endorser yang terkenal ataupun lebih sering menggunakan celebrity endorser, maka akan semakin meningkatkan keputusan pembelian. Apabila konsumen merasa sangat yakin bahwa kualitas produk yang akan dibeli memiliki kualitas yang bagus, maka hal ini akan mendorong semakin yakin untuk mrengambil keputusan membeli produk tersebut.

\section{Hasil Uji Koefisien Determinasi $\left(\mathbf{R}^{\mathbf{2}}\right)$}

Uji Adjusted R Square memberikan angka 0,519 hal ini menunjukkan bahwa variabel keputusan pembelian dipengaruhi oleh variabel promosi media sosial, celebrity endorser dan perceived quality sebesar $52 \%$, sedangkan sisanya sebesar 48 $\%$ dipengaruhi oleh variabel lainnya di luar model penelitian ini.

\section{Uji Hipotesis}

Uji hipotesis dilakukan melalui Uji t. Hasil uji t tersaji dalam Tabel 3 dibawah ini

Tabel 3. Uji t

\begin{tabular}{lcc}
\hline \multicolumn{1}{c}{ Model } & $\boldsymbol{\beta}$ & Sig \\
\hline Promosi Media Sosial & .218 & .031 \\
Celebrity Endorser & .356 & .001 \\
Perceived Quality & .194 & .020 \\
\hline
\end{tabular}

Dependen variabel: Keputusan Pembelian

\section{Pengaruh Promosi Media Sosial terhadap Keputusan Pembelian}

Dari hasil uji t diatas terlihat bahwa promosi media sosial berpengaruh positif ( $\beta$ $=0,218)$ dan signifikan $(\mathrm{p}=0,031)$ terhadap keputusan pembelian Oleh karenanya, hipotesis 1 terdukung. Semakin gencar suatu perusahaan melakukan promosi di media sosial akan semakin memdorong konsumen untuk mengambil keputusan membeli produk Super Track Clothing yang ditawakan perusahaan. Promosi media sosial sangat efektif dalam mempengaruhi keputusan pembelian karena dengan perkembangan era digital, banyak orang baik itu anak - anak hingga orang tua sudah memiliki akun media sosial untuk mengekspos kehidupan kesehariannya, berbelanja online, konten kreator dan ada juga untuk berjualan. hal ini sangat membuat trend positif dalam melakukan promosi dalam bentuk barang atau jasa terhadap keputusan pembelian. Hasil temuan ini mendukung peneltian terdahulu Bate' e (2019); Pamungkas dan Zurhroh (2016); dan Ramadhan (2019) yang menemukan bahwa promosi sosial media berpebgaruh secara signifikan dan positif terhadap keputusan pembelian.

\section{Pengaruh Celebrity Endorser Terhadap Keputusan Pembelian}

Celebrity Endorser berpengaruh positif $(\beta=.356)$ dan signifikan $(p=0,001)$ terhadap keputusan pembelian, sehingga, hipotesis 2 terdukung. Hasil ini memiliki arti bahwa Celebrity Endorser memiliki kekuatan dalam mempengaruhi konsumen untuk mengambil keputusan pembelian. Semakin gencar perusahaan menggunakan Celebrity Endorser akan meningkatkan dorongan bagi konsumen untuk mengambil keputusan membeli produk Super Track Clothing yang diiklankan. Celebrity endorser sebagai alat mediasi menggunakan orang terkenal untuk menaikkan pandangan baik akan suatu produk sehingga dapat mempengaruhi keputusan pembelian konsumen. Walaupun celebrity endorser dapat memakan banyak biaya, dalam segi pemasaran sangat bagus untuk meningkatkan penjualan produk dan memberikan banyak dampak untuk brand menjadi terkenal. Hal ini dapat 
mempengaruhi keputusan pembelian konsumen dalam membeli produk tersebut. Hasil penelitian ini mendukung dengan hasil peneltian dari Oktafiani dan Silaningsih (2015); Kalangi et al. (2019); Bramantya dan Jatra (2016); dan Aysegul et al., (2014) yang dalam penelitiannya menemukan bahwa celebrity endorser memiliki keterkaitan positif terhadap keputusan pembelian

\section{Pengaruh Perceived Quality Terhadap Keputusan Pembelian}

Perceived Quality berpengaruh positif $(\beta=.194)$ dan signifikan $(p=0,020)$ terhadap keputusan pembelian, sehingga, hipotesis 3 terdukung. Hasil ini menunjukkan bahwa semakin bagik persepsi konsumen terhadap kualitas produk Super Track Clothing akan semakin mendorong konsumen untuk mengambil keputusan membeli produk tersebut. Perceived quality (pengaruh kualitas) berpengaruh positif terhadap keputusan pembelian konsumen. Kualitas produk yang diberikan oleh SuperTrack Clothing memiliki kualitas yang baik, sehingga kosumen merasa puas dengan keputusan pembelian produk kaos yang telah dibeli. Hal ini juga didukung dengan adanya celebrity endorser terkenal yang menguatkan konsumen untuk mempercayai bahwa produk kaos tersebut memiliki persepsi kualitas yang baik. Berdasarkan penjelasan terbukti bahwa variable perceived quality berpengaruh siginifikan terhadap keputusan pembelian kaos Supertrack Clothing, hasill ini sesuai dengan hasil penelitian Lie et al. (2017); Rahmadhani dan Sisilia (2019); Octaviyah (2019); dan Putri et al. (2018) yang menemukan bahwa perceived quality berpengaruh terhadap keputusan pembelian.

\section{KESIMPULAN}

Berdasarkan hasil analisis yang telah dibahas pada bab sebelumnya, dapat diberikan kesimpulan sebagai berikut: semakin gencar perusahaan melakukan promosi media sosial akan semakin mendorong konsumen untuk mengambil keputusan pembelian produk SuperTrack Clothing, semakin sering perusahaan menggunakan celeberty endorser akan memperkuat keinginan konsumen untuk mengambil keputusan pembelian terhadap produk SuperTrack Clothing, dan semakin tinggi perceived quality terhadap produk SuperTrack Clothing akan sangat berpengaruh secara positif terhadap keputusan pembelian konsumen.

Penelitian ini juga memiliki keterbatasan, yaitu bahwa penelitian ini hanya menggunakan 3 variabel independen, yaitu media sosial, celebrity endorser, dan perceived quality sehingga penelitian ini belum menjelaskan faktor lain yang mempengaruhi keputusan pembelian konsumen SuperTrack Clothing. Disamoing itu, sampel dan populasi yang digunakan terbatas, hanya 100 sampel dan populasi dan tempat penelitian hanya di Yogyakarta. Oleh karenanya, untuk penelitian selanjutnya disarankan menambah variabel lain, misalnya harga, dan kualitas pelayanan dan menambah jumlah responden sehingga akan bisa memberikan hasil penelitian yang lebih komprehensif.

\section{REFERENSI}

Aaker, David A., 1996., Building Strong Brands, Free Press., New York.

Arikunto. 2006. Prosedur Penelitian Suatu Pendekatan Praktek. Jakarta: PT. Rineka Cipta.

Aysegul, Ermec Sertoglu, Ozlem Catli and Sezer Korkmaz, 2014. Examining the Effect of Endorser Credibility on the Consumers' Buying Intentions: An Empirical Study in Turkey. International Journal of Management and Marketing, Vol. 4 No. 1, pp. 6677

Ayu dan Jatra. 2016. Pengaruh Celebrity Endorser dan Brand Image Terhadap Keputusan Pembelian Yamaha Jupiter MX di Kota Denpasar. 
Denpasar. E-Jurnal Manajemen Unud, Vol 5, No 3.

Bate' e, M. M. (2019). Pengaruh Media Sosial terhadap Keputusan Pembelian di Toko Kaos Nias Gunungsitoli. Jurnal Ekonomi \& Ekonomi Syariah, Vol 2 No 2, pp.313-324.

Bramantya, Y. B., dan Jatra, M. (2016). Pengaruh Celebrity Endorser dan Brand Iamge terhadap Keputusan Pembelian Yamaha Yupiter MX di Kota Denpasar. E-Jurnal Manajemen Unud, Vol.5 No.3, pp. 1745-1771

Devi, M. dan Anom. 2019. Pengaruh Citra Merek, dan Presepsi Kualitas terhadap Keputusan Pembelian Sepatu NIKE. Surabaya: Jurnal Dinamika Administrasi Bisnis Vol 5, No 1.

Gunelius, S. (2011). 30 Minute Social Media Marketing: Step by Step Techniques to Spread the Words about your Business. McGraw-Hill: USA.

Harjati, L. dan Sabu G.L. O. (2014). Pengaruh Persepsi Kualitas Produk Terhadap Keputusan Pembelian the Body Shop. E-Journal WIDYA Ekonomika, Vol. 1 No. 1 pp. 25-30

Kalangi, N. J., Tamengkel, L. F., dan Walangitan, O. (2019). Pengaruh Celebrity Endorser dan Brand Image terhadap Keputusan Pembelian Shampoo Clear. Jurnal Administrasi Bisnis, Vol. 8. No. 1, pp. 44-54

Khasanah, Imroatul. (2015) Analisis Pengaruh Preferensi Merek, Persepsi Kualitas, dan Perceived Value Terhadap Keputusan Pembelian Sepeda Motor Yamaha Matik di Semarang.

Kotler, Philip and Armstrong, G., (2015). Prinsip-prinsip Pemasaran. Edisi. 13. Jilid 1. Jakarta: Erlangga.

Kotler, Philip \& Kevin Lane Keller, K.L. (2016). Marketing Management, 15th Edition, Pearson Education,Inc.

Lie, D.T, Purnomo, D., dan Dewi, K.S. (2017). Pengaruh Persepsi Kualitas
Terhadap Keputusan Pembelian Konsumen pada Keripik Pedas Maicih. Jurnal Cakrawala, pp. 16936248.

Octaviyah, L. (2019) Brand Awareness dan Percieved Quality sebagai Penentu Keputusan Pembelian Ikan Kaleng Mackarel ABC (Studi di Wilayah Kota Surabaya Timur). Jurnal Ilmu Manajemen Vol. 7 No. 4, pp 10871094

Oktafiani, R. dan Sulaningsih, E. (2015). Pengaruh Celebrity Endorser terhadap Keputusan Pembelian Kartu Perdana Xl Di Kota Bogor. Jurnal Visionida, Volume 1 Nomor 2, pp. 45-58

Pamungkas, B. A., dan Zuhroh, S. (2016) Pengaruh Promosi di Media Sosial dan Word of Mouth terhadap Keputusan Pembelian (Studi Kasus Pada Kedai Bontacos, Jombang) Komunikasi, Vol. X No. 02, pp. 145160

Putri, T.A., Marwan, dan Rahmidani, R. (2018). Pengaruh Brand Image dan Percieved Quality Terhadap Keputusan Pembelian Produk La Tulipe di Kota Padang. EcoGen, Vol. 1, No.4-5 , pp. 734-743

Rahmadhani dan Sisilia. 2019. Pengaruh Brand Awareness, Perceived Quality, and Brand Loyalty Terhadap Proses Keputusan Pembelian (Studi di Distribution Store UNKL347 Bandung). Bandung: E-Proceeding Of Management Vol 6.

Ramdhan, J. M. (2019). Pengaruh Media Sosial dan E-Commerce Terhadap Keputusan Pembelian Distro House of Smith. Almana: Jurnal Manajemen dan Bisnis, Vol. 3 No. 3, pp. 534-544 Sangadji dan Sopiah, 2013. Perilaku Konsumen, Cetakan Pertama. Yogyakarta: CV. Andi Offset.

Shimp, Terence. 2003. Periklanan Promosi dan Aspek Tambahan Komunikasi Pemasaran Terpadu. Erlangga. Jakarta: Erlangga. 
JRMB, Volume 16, No. 1, Juni 2021

Sugiyono. 2014. Metode Penelitian Pendidikan Pendekatan Kuantitatif, Tjiptono, Fandy. 2011. Manajemen \& Strategi Merek. Yogyakarta: Andi Kualitatif, dan $R \& D$. Bandung: Offset.

Alfabeta Yogyakarta. 